Иликбаева Евгения Сергеевна

аспирант кафедры уголовного права и криминологии Кубанского государственного университета

\section{ФАЛЬСИФИЦИРОВАННЫЕ ЛЕКАРСТВЕННЫЕ СРЕДСТВА ДЛЯ ВЕТЕРИНАРНОГО ПРИМЕНЕНИЯ КАК КОМПОНЕНТ ПРЕДМЕТА ПРЕСТУПЛЕНИЯ, ПРЕДУСМОТРЕННОГО В СТ. 238.1 УГОЛОВНОГО КОДЕКСА РОССИЙСКОЙ ФЕДЕРАЦИИ}

\begin{abstract}
Аннотация:
В статье рассматривается вопрос о совершенствовании содержания ст. 238.1 УК РФ, в частности путем расширения названного в ней предмета преступления и включения в него указания на фральсифицированные лекарственные средства для ветеринарного применения. Современный российский рынок наводнен фальсифицированными препаратами, предназначенными не только для людей, но и для животных. Вместе с тем не следует забывать, что поддельные ветеринарные лекарственные средства могут стать причиной гибели как животных, так и людей. Однако реализация cm. 238.1 УК РФ при совершении деяний с фальсифицированными лекарственными средствами ветеринарного назначения при буквальном ее толковании невозможна, хотя практика идет по пути расширения. Указанные обстоятельства обусловливают иелесообразность претворения в жизнь высказываемого автором предложения.
\end{abstract}

\section{Ключевые слова:}

лекарственные средства для ветеринарного применения, фальсифицированные лекарственные средства для ветеринарного применения, предмет преступления, оборот фальсифицированных лекарственных средств, квалификация преступления. llikbaeva Evgeniya Sergeevna

PhD student, Criminal Law and Criminal Studies Department, Kuban State University

\section{COUNTERFEIT ANIMAL DRUGS AS A COMPONENT OF A TARGET OF CRIME STIPULATED IN ARTICLE 238.1 OF THE CRIMINAL CODE OF THE RUSSIAN FEDERATION}

Summary:

The study deals with the improvement of Article 238.1 of the Criminal Code of the Russian Federation, in particular by expanding the target of crime named in it and including information on counterfeit animal drugs in it. The modern Russian market is flooded with both human and animal counterfeit drugs. At the same time, we should not forget that counterfeit medicines can cause their death. However, the implementation of Article 238.1 of the Criminal Code of the Russian Federation in case of a counterfeit drug-related crime is impossible on the basis of its literal interpretation, although the case law in this regard is growing. These circumstances determine the feasibility of implementing the proposal made by the author.

Производство и реализация товаров для животных - достаточно прибыльный бизнес. Следует отметить, что на сегодняшний день Государственный реестр лекарственных средств для ветеринарного применения насчитывает около 2228 единиц [1]. Несмотря на это, в настоящее время российский фрармацевтический рынок лекарственных препаратов ветеринарного назначения остается импортно ориентированным. Так, за прошедший год в нашу страну было ввезено 23,9 млн упаковок лекарственных ветсредств на общую сумму 22 млрд р. [2].

О масштабности проблемы оборота фальсифицированных лекарственных ветеринарных препаратов в РФ свидетельствует то, что в результате проведенных Россельхознадзором мероприятий за 2017 г. обеспечено изъятие 112 серий лекарственных средств, качество которых не отвечает установленным требованиям [3]. Российский рынок наводнен фальсифицированными лекарственными препаратами, предназначенными не только для людей, но и для животных. Если о проблеме фральсифицированных, недоброкачественных и незарегистрированных лекарственных средств, предназначенных человеку, СМИ сообщают постоянно, то здоровье домашних питомцев мало кого волнует. Вместе с тем не следует забывать, что фальсифицированные ветеринарные препараты могут стать причиной гибели как животных, так и людей. В частности, на основании данных центра «Биоинженерия», чаще всего подделывают всевозможные витаминные комплексы, глистогонные, противоблошиные средства, гормональные контрацептивы для животных [4].

Следует отметить, что производство фармацевтической продукции, предназначенной для нужд ветеринарной медицины, является весомым фактором формирования экономической эффективности сельскохозяйственного животноводства, содержания здорового поголовья, которое характеризуется высокими продуктивными качествами и необходимой репродуктивной способностью. 
Формированию и развитию области ветеринарной фармации и рынка ветеринарных препаратов в Российской Федерации не придается должного значения. Однако такие процессы, как интеграция в мировое экономическое пространство, интенсификация животноводства, усиленное расширение мирового рынка ветсредств, появление на отечественном рынке широкого ассортимента ветеринарной фрармацевтической продукции зарубежных производителей, распространение антропозоонозных заболеваний, т. е. общих для людей и животных (в частности, туберкулеза, лейкоза, сибирской язвы, ящура и т. д.), актуализировали стратегическое значение устойчивого функционирования и системного государственного регулирования отечественной отрасли ветеринарной фрармации и рынка ветпрепаратов.

Несмотря на важность проблемы, госрегулирование рассматриваемого сегмента фармацевтического рынка на современном этапе недостаточно эффективно. В частности, это проявляется в отсутствии производства в Российской Федерации многих важных для эпизоотического благополучия биологических препаратов и абсолютного большинства субстанций для изготовления химиотерапевтических препаратов, в существовании значительной доли теневого сектора рынка, представленного в основном фальсифицированной, контрафактной продукцией. Именно поэтому, с нашей точки зрения, необходимо статью 238.1 УК РФ дополнить указанием на новый предмет преступления - фральсифицированные лекарственные средства для ветеринарного применения.

Данное обстоятельство осознают представители правоприменительной сореры. Не имея соответствующих правовых установлений, судьи идут на расширительное толкование ст. 238.1 УК РФ, включая в предмет предусмотренного ею преступления ветеринарные препараты.

Так, Собинским городским судом Владимирской области 19.10.2017 г. осужден по ч. 1 ст. 238.1 УК РФ директор ООО «БиоХимФарм». Игнорируя требования о регистрации медицинских изделий, в нарушение требований Федерального закона от 12.04.2010 г. № 61-Ф3 «Об обращении лекарственных средств» и Правил государственной регистрации лекарственных средств для животных и кормовых добавок, утвержденных приказом Министерства сельского хозяйства Российской Федерации от 01.04.2005 г. № 48, подсудимый совершил действия, направленные на серийное получение незарегистрированных лекарственных средств, предназначенных для животных, а именно препаратов «Йодомаст», «Маститрим», «Тримаст», «Неолинк», «Мастисан Б», «Линкомицин 10 \%», «Канамицин 10 \%», «Аскостат», «Левовинизоль», «Бронхопневмозоль», «Неомицина сульфат», «Метрил», присыпки «Эндосепт», «Мастисан Е», «Метромакс» [5].

Вместе с тем, как представляется, данный подход нельзя признать соответствующим закону. Следует отметить, что в Федеральном законе от 12.04.2010 г. № 61-Ф3 «Об обращении лекарственных средств» и Правилах государственной регистрации лекарственных средств для животных и кормовых добавок отсутствуют такие понятия, как «лекарственное средство для ветеринарного применения», «незарегистрированное лекарственное средство для ветеринарного применения», «фальсифицированное лекарственное средство для ветеринарного применения».

Однако закон РФ от 14.05.1993 г. № 4979-1 «О ветеринарии» включает понятие «лекарственные средства для животных». Необходимо обратить внимание и на ГОСТ Р 52682-2006 «Средства лекарственные для ветеринарного применения. Термины и определения» [6], в котором содержатся следующие фоормлировки:

- фальсифицированное лекарственное средство для ветеринарного применения: лекарственное средство, сопровождаемое заведомо ложными сведениями, касающимися его состава и (или) производителя (п. 2.2 ст. 16);

- незаконная копия лекарственного средства для ветеринарного применения: лекарственное средство, поступившее в оборот с нарушением положений отечественного патентного законодательства (п. 2.2 ст. 17);

- недоброкачественное лекарственное средство для ветеринарного применения: лекарственное средство, не отвечающее требованиям, предъявляемым соответствующим нормативным актом, или лекарственное средство с истекшим сроком годности (п. 2.2 ст. 18) [7].

Таким образом, на сегодняшний день не существует четкого определения понятия «лекарственные средства для ветеринарного применения», а также отсутствует законодательная дефриниция незарегистрированного лекарственного средства для ветеринарного применения.

Рынки ветеринарных препаратов и лекарственных средств гуманной медицины тесно взаимосвязаны и формируют единый фрармацевтический рынок, который является частью рынка химической и биотехнологической продукции. В целом анализируя ветеринарный рынок страны, можно заметить, что за последние годы возрос спрос на товары российского производства. Отечественные игроки активно укрепляют позиции, выпуская высококачественные, конкурентоспособные относительно европейских аналогов препараты. Тем самым расширяется рынок и возникают все новые способы подделки фральсифицированных лекарственных средств для ветеринарного применения. 
При этом законодатель не решает проблемы ветеринарной отрасли, на территории Российской Федерации отсутствует единый федеральный закон о лекарственных средствах ветназначения. Это способствует развитию и распространению фальсифицированных лекарственных препаратов для животных.

Нельзя признать в полной мере разработанными и положения уголовного закона в части регламентации предмета преступления, предусмотренного в ст. 238.1 УК РФ. Указание в нем на лекарственные средства отсылает правоприменителя к Федеральному закону от 12.04 .2010 г. № 61-Ф3 «Об обращении лекарственных средств», в котором не идет речь о препаратах, используемых в ветеринарии. Исходя из этого, очерченный нормой круг компонентов предмета названного преступления при ее толковании, на наш взгляд, не подлежит расширению. Однако опасность фальсификации лекарственных средств ветеринарного назначения достаточно высока и экстраполируется на общественные отношения в сфере обеспечения безопасности здоровья населения. Последнее может быть подвергнуто угрозе в случаях возникновения эпизоотий, остановить распространение которых с помощью поддельных препаратов невозможно; при использовании в пищу продуктов животного происхождения, полученных от скота, потреблявшего фральсифицированные ветпрепараты и вследствие этого нездорового; и пр.

Вместе с тем, как известно, точное установление предмета преступления крайне важно для правильной уголовно-правовой оценки содеянного [8]. Ошибки, связанные с его определением, чреваты незаконным осуждением или оставлением безнаказанными деяний, обладающих высоким уровнем общественной опасности.

Можно заключить, что противодействие обращению незарегистрированных и фальсифицированных лекарственных средств для ветеринарного применения, включая уголовно-правовые средства, является актуальной проблемой. Применение указанных препаратов способствует снижению эфффективности лечебно-профилактических и противоэпизоотических мероприятий, что негативно отражается не только на здоровье сельскохозяйственных и домашних животных, но и на жизни и здоровье человека, в том числе через поступления на рынок животноводческой продукции с остаточными количествами поддельных лекарств. Все это требует дальнейшего совершенствования содержания ст. 238.1 УК РФ, например путем расширения круга компонентов названного в ней предмета преступления с помощью введения указания на фральсифицированные лекарственные средства для ветеринарного применения.

\section{Ссылки:}

1. Государственный реестр лекарственных средств для ветеринарного применения [Электронный pecypc]. URL: https://galen.vetrf.ru/\#/registry/pharm/registry?page=1 (дата обращения: 10.05.2018).

2. Выросла дробность упаковок ветеринарной продукции, поставляемой в Россию [Электронный ресурc]. URL: https://gmpnews.ru/2018/04/vyrosla-drobnost-upakovok-veterinarnoj-produkcii-postavlyaemoj-v-rossiyu (дата обращения: 10.05.2018).

3. Актуальная информация о наименованиях и сериях лекарственных препаратов для ветеринарного применения, реализация которых приостановлена [Электронный ресурc]. URL: http://www.fsvps.ru/fsvpsdocs/ru/regLicensing/docs/farmakonadzor/lek_stop20180406.pdf (дата обращения: 10.05.2018).

4. Поддельные ветпрепараты опасны для здоровья животных [Электронный pecypc]. URL: http://www.kitty.ru/Farmacy/poddelka.htm (дата обращения: 10.05.2018).

5. Приговор № 1-1-229/2017 по делу № 1-1-229/2017 [Электронный ресурс] : от 19 окт. 2017 г. URL: http://sudact.ru/regular/doc/AbFdERbdWoJX (дата обращения: 10.05.2018).

6. ГОСТ P 52682-2006. Средства лекарственные для ветеринарного применения. Термины и определения (с поправкой) [Электронный ресурc]. URL: http://docs.cntd.ru/document/1200050767 (дата обращения: 10.05.2018).

7. Там же.

8. См. подробнее: Гаухман Л.Д. Квалификация преступлений: закон, теория, практика. 2-е изд., перераб. и доп. М., 2003. С. 82-83 ; Музика А.А., Лащук Є.В. Предмет злочину: теоретичні основи пізнання : монографія. Київ, 2011 ; Российское уголовное право. Общая часть / под ред. В.П. Коняхина, М.Л. Прохоровой. М., 2014. С. 177-182

\section{References:}

Gauchman, LD 2003, Qualification of crimes: law, theory, practice, 2nd ed., Moscow, pp. 82-83, (in Russian). Konyakhin, VP \& Prokhorova, ML (eds.) 2014, Russian criminal law. General part, Moscow, pp. 177-182, (in Russian). Muzyka, AA \& Lashchuk, EV 2011, The target of crime: the theoretical basis of awareness, monograph, Kyiv, (in Ukrainian). 